\title{
O teoriji i praksi skupno osmišljenog kazališta
}

\section{Kačić Rogošić, Višnja. Skupno osmišljeno kazalište. Opće značajke i hrvatski primjeri. Hrvatski centar ITI, 2017. str. 351.}

Krajem 2017. godine u biblioteci Mansioni, u izdanju hrvatskog centra ITI objavljena je knjiga teatrologinje Višnje Kačić Rogošić pod naslovom Skupno osmišljeno kazalište. Opće značajke i hrvatski primjeri. Navedena monografija prerađena je doktorska disertacija, obranjena 2013. godine na Filozofskom fakultetu Sveučilišta u Zagrebu.

Pojam skupno osmišljenog kazališta, prema autorici monografije (8), odnosi se na kazališne predstave koje ne nastaju uprizorenjem nekog postojećeg predloška (dramskog teksta, libreta, scenarija, koreografskog zapisa) već se njihov ukupni izvedbeni materijal u potpunosti proizvodi, pronalazi djelomično proizveden, razvija, organizira i povezuje zajednički, tijekom radioničke faze otkrivanja novoga, a ponekad i tijekom same izvedbe. Navedena izvedbena vrsta je, prije svega, određena odbacivanjem neupitnog autoriteta dramskog pisca, redatelja i unaprijed napisanog teksta. U svojim početcima pozicionirala se na alternativnoj i društveno-angažiranoj sceni. Odstupa od stvaralačke hijerarhije, razvija kreativni egalitarizam i skupni kreativni identitet, uvodi novi način odnošenja kako prema publici tako i prema izvedbenim prostorima te istražuje različite načine tjelesne i neverbalne ekspresije. Ta se izvedbena vrsta pojavila šezdesetih godina 20. stoljeća, nadahnuta idealima kontrakulture, u Sjevernoj Americi, gdje je fenomen i prvi put imenovan, a potom i u Europi. U Hrvatskoj se izvedbena vrsta razvila tijekom sedamdesetih godina prošlog stoljeća, zahvaljujući, poglavito, IFSK-u, Danima mladog kazališta i djelovanju SEK-a. Najpoznatije kazališne skupine, u svjetskim okvirima, čiji se rad temeljio na principima skupnog osmišljavanja su 
Living Theatre, Open Theatre, San Francisco Mime Troupe, The Wooster Group, The Performance Group, Le Théâtre du Soleil, Gob Squad, Forced Entertainment, Goat Island itd.

U knjizi, koja predstavlja vrijedan prilog hrvatskoj znanosti o kazalištu, sustavno je predstavljena izvedbena vrsta za koju se u različitim kulturnim i jezičnim sredinama koriste posve različiti pojmovi: la création collective, Kollektive Arbeit, Collective Creation, Collaborative Creation, Devised Theatre, Group devised theatre i Collaboratively devised theatre. U Hrvatskoj su se dosad za opis izvedbene vrste u pitanju najčešće koristili pojmovi kolektivna režija, autorsko kazalište ili autorski projekt. U uvodnom dijelu studije Kačić Rogošić ukazuje na terminološke neujednačenosti te predlaže hrvatsku inačicu naziva za izvedbenu vrstu: skupno osmišljeno kazalište, čime uvodi novi pojam u hrvatsku znanost o književnosti i kazalištu.

Monografija Skupno osmišljeno kazalište. Opće značajke i hrvatski primjeri podijeljena je na dva dijela. U prvom se dijelu problematizira fenomen skupnog osmišljavanja tijekom 1960-ih i 1970-ih godina, a u drugom u suvremenosti. Autorica teorijski pristupa razlikama i sličnostima skupnog osmišljavanja u svjetskoj kazališnoj praksi, bavi se pitanjima razlikovnih značajki od drugih vrsta izvedbe, obrađuje pitanje izvedbene zajednice u skupno osmišljenom kazalištu, opisuje procese skupnog osmišljavanja, kao i odnos prema publici i izvedbenom prostoru. Potom, u drugom dijelu knjige, problematizira statusni obrat skupnog osmišljavanja u suvremenosti, pitanje rubova skupno osmišljenog kazališta, napuštanje ideala zajedništva, zaokret od kolektiva prema suradnji te institucionalizaciju vrste ulaskom u kazališne kuće i festivale srednje struje.

U zasebnim poglavljima obrađuje odabrane primjere iz hrvatskog kazališta, tj. piše četiri studije slučaja detaljno analizirajući principe na kojima počiva, ili je počivalo, djelovanje Pozdrava, Kugla glumišta, Bacača sjenki te Bobe Jelčića i Nataše Rajković. Pri pisanju ovog izvornog dijela studije korišteni su arhivski materijali kazališnih skupina o kojima piše i brojnih hrvatskih kazališta, kao i informacije dobivene tijekom razgovora sa samim kazališnim umjetnicima, na radionicama na kojim je autorica sudjelovala te na temelju uvida stečenih tijekom praćenja proba.

Tekst je popraćen brojnim fotografijama, iscrpnim popisom literature, kazalom imena, pogovorom Borisa Senkera te bilješkom o autorici. 
Monografija Višnje Kačić Rogošić vrijedan je prilog hrvatskoj teatrologiji stoga što na iscrpan i teorijski osviješten način progovara o izvedbenoj vrsti o kojoj na hrvatskom jeziku postoji iznimno malo literature, no posebice stoga što prva sustavno obrađuje segment hrvatskog kazališta koji dosad nije bio obrađen te objašnjava kako se proces skupnog osmišljavanja kazališta razvijao u hrvatskom kazalištu tijekom posljednja četiri desetljeća. Kao takva zasigurno će biti korisno i poticajno štivo teatrolozima, studentima filoloških i umjetničkih usmjerenja te kazališnim umjetnicima i kritičarima.

\section{(c) (i) (9)}

Creative Commons Attribution-NonCommercial-NoDerivatives 4.0 International License 